\title{
505 振動を利用した鍀造中子のバリ取り
}

\author{
Deburring Characteristics of Sand Core Using Vibration \\ ○正 青 木 繁（都立高専） \\ 戸澤 幸一（日産自動車） \\ 武 藤一夫（職業能力開発総大） \\ 平 井 聖 児 (都立高専) \\ 吉田 雄 次 (日産自動車)
}

Shigeru Aoki, Tokyo Metropolitan College of Technology, 1-10-40 Higashi-Ohi Shinagawa-ku, Tokyo

Seiji Hirai, Tokyo Metropolitan College of Technology

Koichi Tozawa, Nissan Motor Co. Ltd.

Yuji Yoshida, Nissan Motor Co. Ltd.

Kazuo Muto, Polytechnic University

Key Words : Vibration, Deburring, Sand Core, Casting, Media

\section{1. 緒言}

鋳造は自動車のエンジンなどの多くの構造体に使われて いる加工法である。鋳造は構造体を一体化できるため、強 度上の利点があり、振動に対する减衰効果もできる。一方、 製品に巣が入ることがある、バリがあるなどの久点もある。 製品のバリについては切断・研削等の方法で取り除く。し かしながら、鋳造中子にもバリがある場合がある。これは、 金型を加熱して鋳造中子を焼成するために、砂による金型 の摩耗と変形によってできる。変形しやすい大型で扁平な 型を用いたときに生じやすく、鋳造中子の隅部や合わせ面 に生じる。鋳造中子のバリは製品の傷の原因になる。この ことを避けるために、現状ではバリを手作業で取り除いて いる。また、一部ではロボットを使っているが、十分に取 り除くことができないのが現状である。このバリ取り作業 を簡単な方法で自動化できるようにすれば、作業能率を向 上させることができる。

本報告では、振動を利用して鋳造中子のバリ取りをする 方法について検討する。バリのある中子を振動するメディ アの中に入れ、加振振幅や加振振動数、振動を加える時間、 メディアの形状などを変えてバリの取れ具合を測定した。 また、中子の減量を測定した。その結果、この方法が鋳造 中子のバリ取りに有効であることが明らかになった。

\section{2. 実験方法}

\section{1 鋳造中子}

実験で用いた鋳造中子の形状および寸法を図 1 に示す。 原砂は硅砂 (パールサンド)、種類はシェル砂で粒度は 5.5 号、抗折力は $51.6 \mathrm{kgf} / \mathrm{cm}^{2}$ のものを用いた。中子の製造工程 は次のとおりである。

1. 砂を摜拌しながら過熱し、混練機に入れてレジンを加

え、熱で溶けたレジンを砂粒のまわりに均一にコーティン グする。

2.コーティングした砂を中子造型機に送る。(この時点で は砂同土はくっつかないさらさらの状態）

3. 造型機に取り付けた中子用の金型に砂を空気圧で吹き 込む。

4. 金型はあらかじめガスバーナーまたは電気ヒーターで 加熱し、 $200^{\circ} \mathrm{C}$ から $300^{\circ} \mathrm{C}$ に維持しておく。

5. 型内で金型の熱で加熱されたレジンは溶けてくっつき 合い、硬化して固まる。

6. 硬化後、金型を開いて中子を取り出す。

7 . 中子のバリと吹き込み口部をヤスリで除去する。（取り 出し、バリ取りは一部ロボット化で自動化）

\section{8. 目視検查および運搬}

\section{2 振動実験}

振動メディアとしては、 $\phi 4$ セラミック球、各辺 $4 \mathrm{~mm}$ の 三角柱セラミック、 $\phi 2$ スチールショット、 $\phi 1.5$ ガラスビー ズを用いた。この中で、 $\phi 2$ スチールショット、 $\phi 1.5$ ガラス ビーズではバリを取ることができなかった。また、 $\phi 5$ プラ スティックも用いた。

\section{3. 実驗結果}

\section{1メティアの効果}

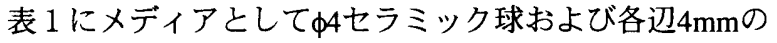
三角柱セラミックを用いた場合の結果を示す。加振振動数 は50Hzとし、加振する時間は20秒とした。メディアとして 中4セラミック球を用いた場合には、メディアにA方向（絴方 向）に中子を挿入すると、上方のバリが残った。バリ面を 下にして水平に埋め込んだ場合には、加振振幅が9Gおよび 6Gの場合にはバリが取れた。加振振幅が4.2Gの場合にはバ リが少し残った。メディアとして各辺 $4 \mathrm{~mm}$ の三角柱セラミ ックを用いた場合には、加振振幅が9Gの場合にはバリが取 れた。加振振幅が $6 \mathrm{G}$ の場合にはバリが少し残り、4.2Gの場 合にはバリが大きく残った。三角柱セラミックは流動性が 悪く、加振中に㨂入することができなかった。

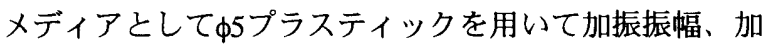
振する時間を変えて、中子の減量について詳細に検討した。 表 2 に選択した加振振動数および加振振幅を示す。図 2 に 10秒ごとに測定した減量のグラフを示す。この図から、加 振した変位振幅が大きいほど减量が大きくなる傾向がみら れる。

図 3 に、20秒加振した場合の加振振幅と中子の減量の関 係を示す。図 $3(\mathrm{a})$ では横軸に加振した変位振幅（全振幅） をとり、図 3(b)では横軸に加振した加速度振幅とった。こ の場合、変位振幅が大きくなるほど中子の減量が大きくな る傾向がみられる。加速度振幅については、振幅が大きく なるほど減量が少なくなる傾向がみられるが、同じ加速度 振幅については変位振幅が大きいほど減量が大きい。

\section{4. 結言}

振動を利用して鋳造中子のバリ取りをする方法について 検討した。バリのある中子を振動するメディアの中にバリ のある鋳造中子を入れ、加振振幅や加振振動数、振動を加 える時間、メディアの形状などを変えてバリの取れ具合を 測定し、中子の減量を測定した。その結果、メディアの形 状は球形がよく、ある程度以上の径が必要であるといえる。 また、加振振幅や加振振動数、振動を加える時間を適切に 


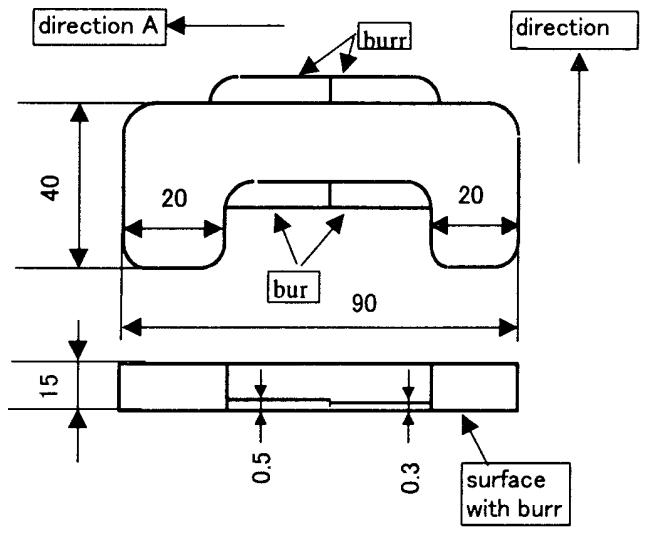

Fig.1 Shape and size of specimen

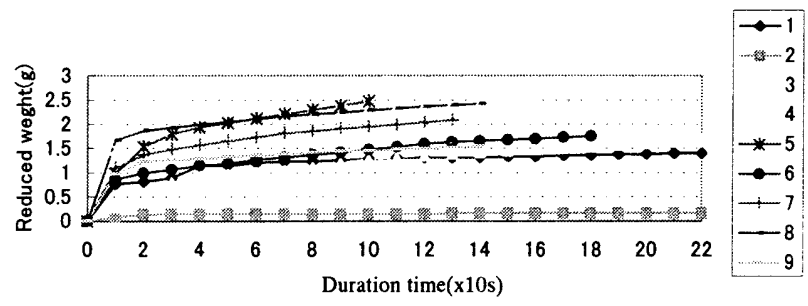

Fig.2 Reduced weight of specimen

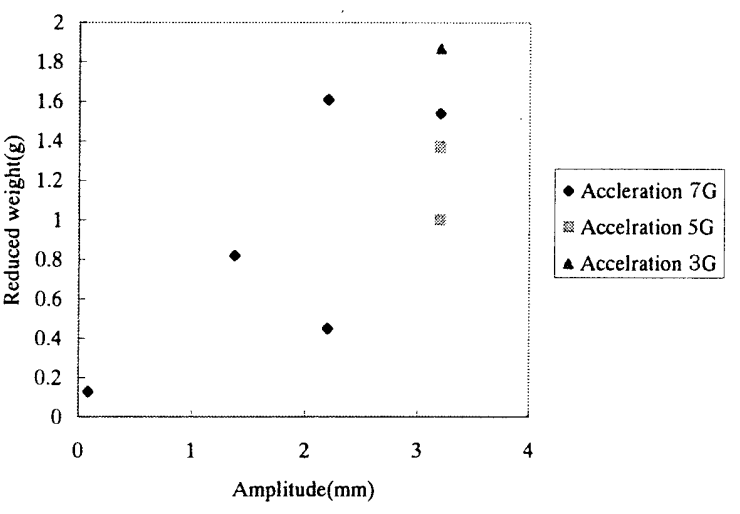

(a)For various acceleration

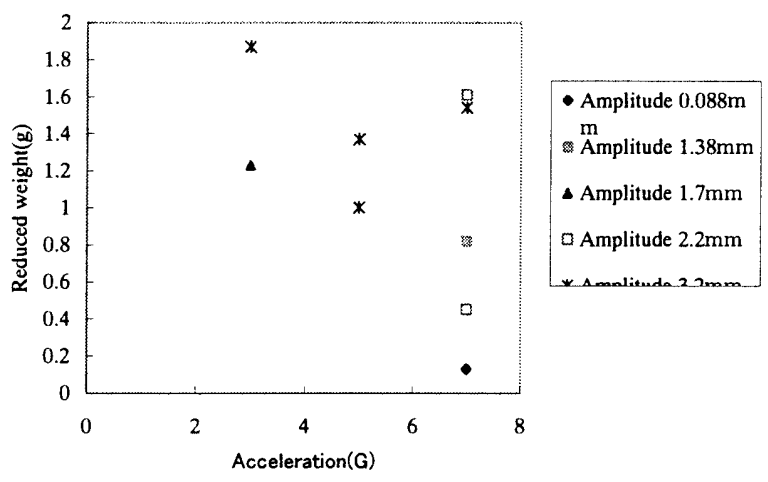

(b)For various displacement

Fig.3 Reduced weight of specimen (20 seconds)

Table 1 Experiment using some vibration media

\begin{tabular}{|c|c|c|c|c|c|c|c|c|}
\hline Media & \multicolumn{4}{|c|}{$\begin{array}{l}\text { Ceramic Ball(Diameter } 4 \mathrm{~mm} \text { ) } \\
\text { Media for grinding } \mathrm{AH}-\mathrm{B} 4\end{array}$} & \multicolumn{4}{|c|}{$\begin{array}{l}\text { Triangular Prism } \\
\text { (each side } 4 \mathrm{~mm} \text { ) AH-T4 }\end{array}$} \\
\hline Frequency & \multicolumn{4}{|l|}{$50 \mathrm{~Hz}$} & \multicolumn{4}{|l|}{$50 \mathrm{~Hz}$} \\
\hline Acceleration $(\mathrm{G})$ & 8.5 & 9 & 6 & 4.2 & 9 & & 6 & 4.2 \\
\hline Duration(s) & 20 & 20 & 20 & 20 & 20 & & 20 & 20 \\
\hline Direction & $\begin{array}{l}\text { Insert by } \\
\text { hand } \\
\text { vertically }\end{array}$ & \multicolumn{3}{|c|}{$\begin{array}{l}\text { Buried into media horizontally } \\
\text { lower surface with burr }\end{array}$} & \multicolumn{4}{|c|}{$\begin{array}{l}\text { Buried into media horizontally } \\
\text { lower surface with burr }\end{array}$} \\
\hline Results & $\begin{array}{l}\text { Lower } \\
\text { surface } \\
\text { is rough }\end{array}$ & Completed & Completed & $\begin{array}{l}\text { Incomplete } \\
\text { small burr } \\
\text { at corner }\end{array}$ & Completed & & $\begin{array}{l}\text { mplete } \\
\text { ll burr } \\
\text { orner }\end{array}$ & $\begin{array}{l}\text { Incomplete } \\
\text { large burr } \\
\text { at corner } \\
\end{array}$ \\
\hline
\end{tabular}

Table 2 Experiment number

\begin{tabular}{|l||l|l|l|l|l|l|l|l|l|}
\hline Experiment No. & 1 & 2 & 3 & 4 & 5 & 6 & 7 & 8 & 9 \\
\hline \hline Frequency $(\mathrm{Hz})$ & 50 & 200 & 40 & 40 & 33 & 28 & 28 & 22 & 3 \\
\hline Amplitude(G) & 7 & 7 & 7 & 7 & 7 & 5 & 5 & 3 & 3 \\
\hline Amplitude(mm) & 1.38 & 0.088 & 2.2 & 2.2 & 3.2 & 3.2 & 3.2 & 3.2 & 1.7 \\
\hline
\end{tabular}

